\title{
FIRST pin/pin MICROMORPH MODULES BY LASER PATTERNING
}

\author{
Steve Golay, Johannes Meier, Sébastien Dubail, Sylvie Faÿ, Ulrich Kroll, Arvind Shah \\ Institute of Microtechnology (IMT), Rue A-L. Breguet 2, CH-2000 Neuchâtel, Switzerland
}

\begin{abstract}
The well-established laser-scribing currently used for a-Si:H module fabrication, has been applied to

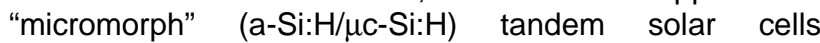
deposited on glass/ZnO substrates. Thereby, a laser at a wavelength of $1064 \mathrm{~nm}$ was used for scribing the $\mathrm{ZnO}$ and a laser with a wavelength of $532 \mathrm{~nm}$ for the silicon film scribing. It is shown that with glass-side scribing, both the $0.3 \mu \mathrm{m}$ thick a-Si:H top cell as well the $3 \mu \mathrm{m} \mu \mathrm{c}-\mathrm{Si}: \mathrm{H}$ bottom cell can be patterned in one single pulse. Monolithic integrated series connection is obtained with a total of 3 patterning steps. These first experiments allowed for fabrication of micromorph mini-modules (area 23.3 $\mathrm{cm}^{2}$ ) having 6 segments has been fabricated with a stable aperture efficiency of $9.1 \%\left(\mathrm{~V}_{\mathrm{oc}}=8.014 \mathrm{~V}, \mathrm{FF}=66.6 \%\right.$, $\mathrm{I}_{\mathrm{sc}}=39.72 \mathrm{~mA}$ ).
\end{abstract}

\section{INTRODUCTION}

The micromorph (a-Si:H/ $/ \mathrm{c}-\mathrm{Si}: \mathrm{H})$ tandem concept is at present to be considered as one of the most promising future concept for thin-film solar cells. This cell concept represents a "true" tandem structure (with spectral sharing) having a $\sim 0.2-0.3 \mu \mathrm{m}$ thick amorphous silicon (a-Si:H) top cell and a 1-3 $\mu$ m thick microcrystalline silicon $(\mu \mathrm{c}-\mathrm{Si}: \mathrm{H})$ bottom cell. Sofar, stabilised cell efficiencies between 11 and $12 \%$ have been obtained on laboratory scale for cells with around $1 \mathrm{~cm}^{2}$ area [1 - 6].

An important question for every thin-film solar cell concept is the application of the integrated series connection technique [7], in order to upscale production technology for entire large-area $\left(1 \mathrm{~m}^{2}\right)$ modules. Compared to conventional crystalline wafer-based modules, the application of this technique allows a reduction of the costs for thin-film solar cell module manufacturing. In case of amorphous silicon based solar cells, the laser-scribing method has already been well-established in the fabrication of $\sim \mathrm{m}^{2}$-size modules.

Therefore, it is of particular interest to know if patterning of the much thicker micromorph pin/pin tandems $(1-3 \mu \mathrm{m})$ is applicable, by the standard laser scribing technique, without damaging the cell [8]. In this work, we present first results on laser patterning of $\sim 3 \mu \mathrm{m}$ thick micromorph tandem cells.

Of particular importance for the performance of thin-film silicon solar cells are the TCO (transparent conductive oxide) contact layers. IMT has therefore developed its own "in-house" TCO technology, LP-CVD (low-pressure chemical vapor deposition) of zinc oxide $[9,10]$. The experiments described here were carried out on solar cells using such TCO contact layer.

\section{EXPERIMENTAL}

Micromorph p-i-n/p-i-n [1-3] cells have been deposited by the Very High Frequency Glow-Discharge (VHF-GD) technique [9] on glass/ZnO substrates. The zinc oxide front-TCO has been deposited by the LP-CVD technique. Further results of single-junction $\mathrm{p}-\mathrm{i}-\mathrm{n}$ a-Si:H solar cells on these $\mathrm{ZnO}$ layers will be given in another paper at this conference [10]. The rough zinc oxide is deposited on Schott AF45 glass substrates. For the deposition of the cells a small-size VHF reactor of $8 \times 8 \mathrm{~cm}^{2}$ substrate electrodes was disposable. Within this area, mini-modules have been segmented.

For the patterning of the integral series connection an $\mathrm{Nd}$ :YAG laser of wavelength 1064 and a $\mathrm{Nd}: \mathrm{YVO}_{4}$ laser of $532 \mathrm{~nm}\left(\mathrm{TEM}_{00}\right)$ have been arranged in order to scribe with a computer controlled $x-y$ table in a pulse frequency range of 1 to $100 \mathrm{kHz}$. Energies between $10-50 \mu \mathrm{J}$ for the green and $100-750 \mu \mathrm{J}$ for the infrared scribe have been used. The laser light optics was adjusted to obtain scribe line widths in the range of $10-60 \mu \mathrm{m}$, for both 1064 $\mathrm{nm}$ and $532 \mathrm{~nm}$ wavelengths.

For the structuration of small test cells $\left(0.25-1 \mathrm{~cm}^{2}\right)$, the $\mathrm{Nd}: \mathrm{YVO}_{4}$ laser has been applied. Hereby, the scribing of the test cell was performed through the glass substrate. The patterning from the glass-side offers the possibility of a direct explosive ablation of the entire $2-3 \mu \mathrm{m}$ thick micromorph cell by one single pulse.

The first step in the fabrication of a mini-module of several segments consists in electrically isolating the front TCO segments. This front contact scribe is realised here by the $1064 \mathrm{~nm}$ infrared laser and is illustrated as "Pattern \#1" in Fig. 1. To form the desired series connection, the patterning of steps \#2 and \#3 were performed, by applying now the $532 \mathrm{~nm}$ laser.

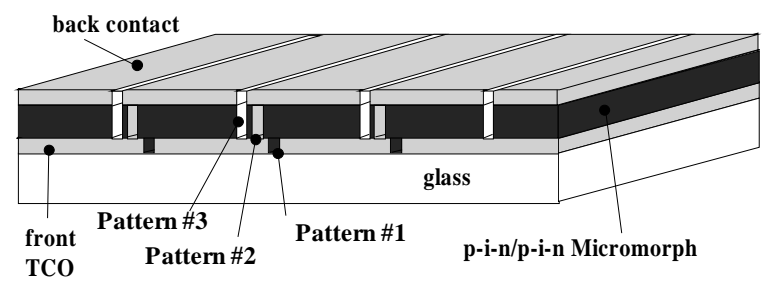

Fig 1: Applied steps of patterning for the monolithic series connection of micromorph thinfilm solar cells modules. 
Using another set-up of the computer controlled $x$-y table; it is possible to perform Light Beam Induced Current (LBIC) measurements by scanning the areas of the patterned test cells. Hereby, a focalized laser diode with a wavelength of $670 \mathrm{~nm}$ was used. This LBIC characterization gives information about the quality of the cell borders zones. The induced current can then be mapped in a 2-dimensional image. Apart from monitoring the properties of the cell borders, the LBIC images allow, furthermore, to identify inhomogeneities, as originating e.g. from pinholes, within the cell area. Light-soaking experiments were carried out for our test cells and micromorph modules under AM1.5 close conditions $\left(50^{\circ} \mathrm{C}\right.$, $1000 \mathrm{~W} / \mathrm{m}^{2}$ and $1000 \mathrm{~h}$ ).

The test cells and the modules were characterised by AM1.5 I-V measurements (WACOM solar simulator WXS140S-10) and spectral response (SR) measurements.

Details of the scribed trenches have been analyzed by Scanning Electron Microscopy (SEM).

\section{RESULTS AND DISCUSSION}

\section{Glass-side patterning}

In order to search for possible loss mechanisms in the micromorph module fabrication steps, test cells of $1 \mathrm{~cm}^{2}$ size have also been prepared. They were subjected to both layer-side and glass-side scribing [8]. In contrast to layer-side scribing, we observed that the patterning from the glass-side offers the possibility of a direct explosive ablation of the entire $2-3 \mu \mathrm{m}$ thick micromorph cell. Obviously, only one single pulse is sufficient to remove the Si-film down to the bare front-TCO as can be seen in Fig. 2: every pulse shot can clearly be identified in the SEM picture. A closer look at the dark scribe borders

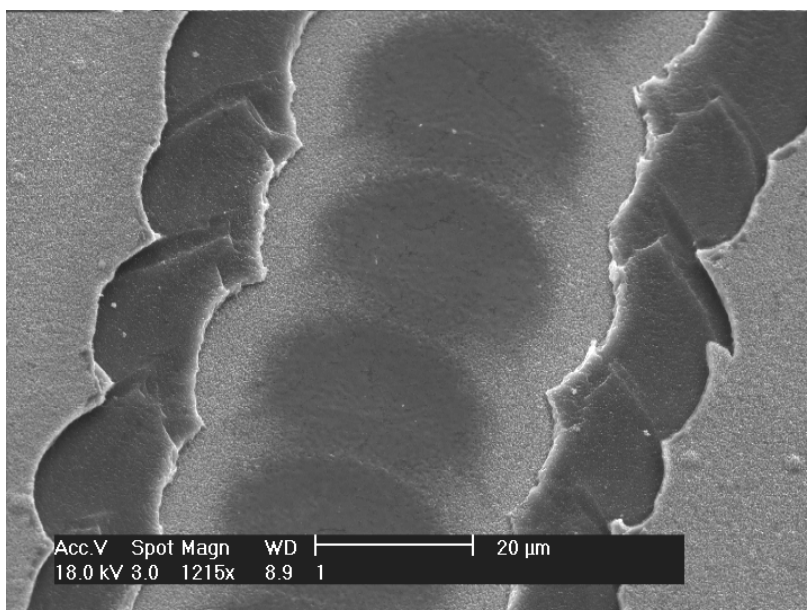

Fig. 2: SEM picture of the of a micromorph test cell.

reveals that besides the ablation of the back contact there must also be a removal of a part of the $\mu \mathrm{c}-\mathrm{Si}: \mathrm{H}$ bottom cell. As in this dark region the cell is no more active (due to the absence of the back contact) this defective area does not influence the performance of the micromorph tandem cell. However, these dark stripe borders represent a scribe loss of an additional $\sim 20 \mu \mathrm{m}$ width, which has to be added to the area losses of Pattern \#3 in the series connection of a module.

Indeed, our I-V AM1.5 characteristics confirm high fill factors of over $72 \%$ indicating that shunt effects due to the scribing process are not present. Micromorph tandem cells patterned by glass-side scribing reveal their full solar cell performance with respect to open circuit voltage as well as with respect to the short circuit current. Furthermore, our LBIC measurements show that no disturbances at the scribed border zones of the cells are present. This is demonstrated with a flat signal over the whole cell area (Fig. 3). LBIC at this wavelength is very sensitive to damage at the a-Si:H top cell [8] (the ratio of bottom cell/top cell LBIC-signal contribution is approximately $1: 4)$.

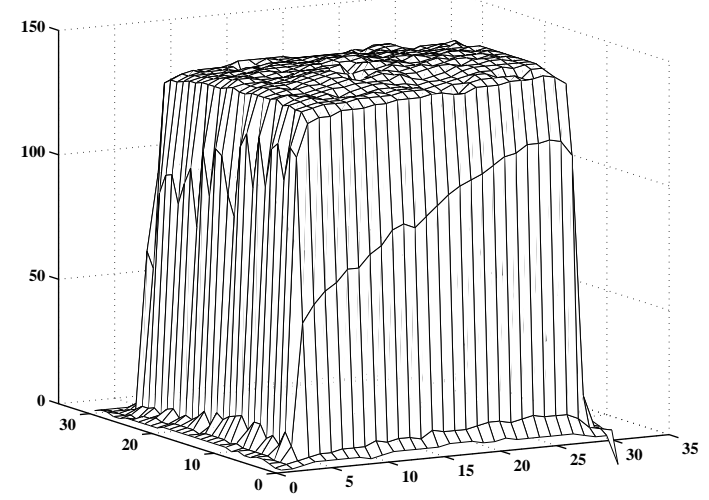

Fig. 3: LBIC mapping $(\lambda=670 \mathrm{~nm})$ of a $2.5 \times 2.5 \mathrm{~mm}^{2}$ micromorph cell patterned from the glass-side.

\section{Micromorph module fabrication}

Based on the encouraging results of test cell patterning as described above, first micromorph modules with integrated monolithic series connection have been explored within the maximum disposable deposition area of $8 \times 8 \mathrm{~cm}^{2}$. The widths of the single scribe trenches are different from each other (see Fig. 4); their optimization is

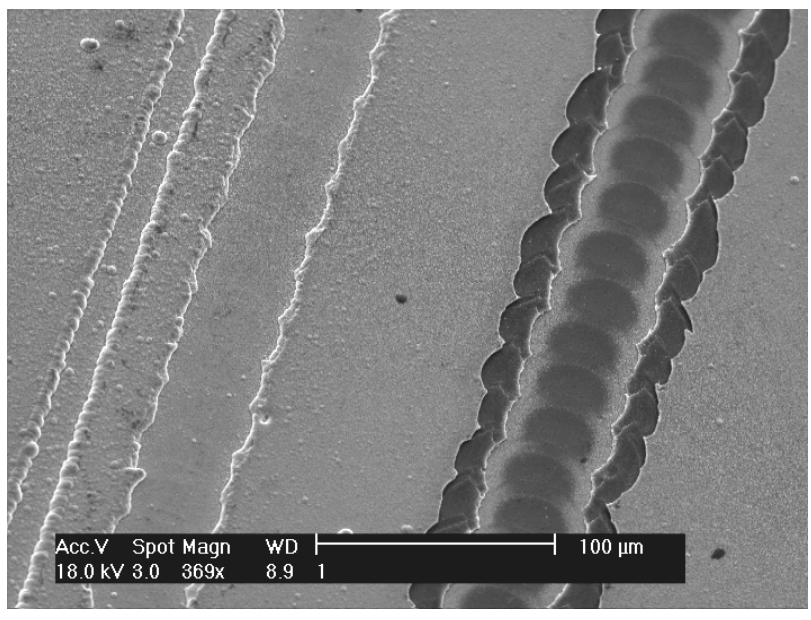

Fig. 4: SEM micromorph of the 3 different pattern lines. 
now the subject of further investigations and optimizations. We have sofar a scribe loss of the three lines of approximately 250 - $300 \mu \mathrm{m}$ achieved. This should indeed be optimized in order to reduce the scribe losses further. For modules, a design consisting of 6 segments has been chosen. Hereby, the widths of the segments were between $8-15 \mathrm{~mm}$ : a choice that needs, of course, further optimisation to maximise the cell's active surface and to minimise the fill factor (FF) losses by the series resistance of the front TCO. A typical IMT micromorph mini-module is given in Fig. 5.

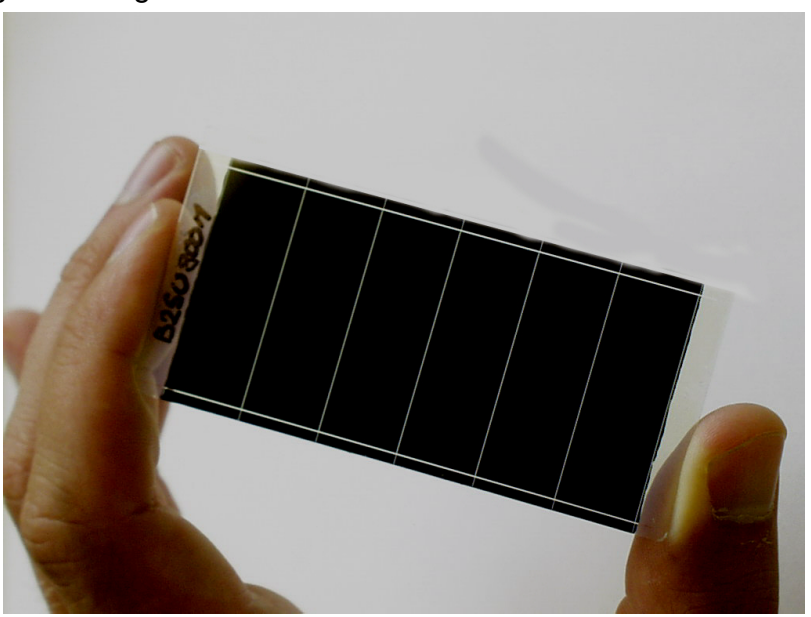

Fig. 5: Picture of a laser patterned $8 \times 4 \mathrm{~cm}^{2} \mathrm{p}-\mathrm{i}-\mathrm{n} / \mathrm{p}-\mathrm{i}-\mathrm{n}$ micromorph module. This module is fully fabricated within IMT's "in house" TCO (LPCVD ZnO) technology.

The finished modules were compared with test cells $\left(1 \mathrm{~cm}^{2}\right)$ of the same deposition run in order to study discrepancies and fabrication effects on the basis of the I-V characteristics. We observed a very close correspondence of the solar cell parameters between small $1 \mathrm{~cm}^{2}$ test cells and the whole module of $23.3 \mathrm{~cm}^{2}$ size (see an example in Table I). This proves that we have

Table I: Comparison of micromorph cell parameters under AM1.5 illumination of a $1 \mathrm{~cm}^{2}$ cell and a $23.5 \mathrm{~cm}^{2}$ size module in the initial and light-soaked state $\left(50^{\circ} \mathrm{C}\right.$, $1000 \mathrm{~W} / \mathrm{m}^{2}$ and $1000 \mathrm{~h}$ ). The $\mathrm{V}_{\mathrm{oc}}$ and the FF correspond to the performance of the whole 6-segmented module, whereas the given $\mathrm{J}_{\mathrm{sc}}$-value corresponds to the minimal current density of one of the 6 segments.

\begin{tabular}{|l|c|c|c|c|}
\cline { 2 - 5 } \multicolumn{1}{c|}{} & \multicolumn{2}{c|}{ test cell $\left(1 \mathrm{~cm}^{2}\right)$} & \multicolumn{2}{c|}{ module $\left(23.3 \mathrm{~cm}^{2}\right)$} \\
\cline { 2 - 5 } \multicolumn{1}{c|}{} & initial & degraded & initial & degraded \\
\hline $\mathrm{V}_{\mathrm{oc}}[\mathrm{V}]$ & 1.348 & 1.336 & 8.04 & 8.04 \\
\hline $\mathrm{FF}$ & 71.3 & 67.3 & 71.2 & 67 \\
\hline $\mathrm{J}_{\mathrm{sc}}\left[\mathrm{mA} / \mathrm{cm}^{2}\right]$ & 10.35 & 10.31 & 10.32 & 10.30 \\
\hline
\end{tabular}

an excellent control on the homogeneous deposition for the micromorph tandem cell. Even after light-soaking there is no significant difference in the principal solar cell parameters of the test cell and the module over the $8 \times 8 \mathrm{~cm}^{2}$ electrode areas.

\section{Stabilised micromorph module}

On our modules we checked the stability by performing standard light-soaking experiments $\left(50^{\circ} \mathrm{C}, 1000 \mathrm{~W} / \mathrm{m}^{2}\right.$ and $1000 \mathrm{~h}$ ). The I-V characteristic of our best module is given in Fig. 6 in the stabilized state, i.e. after light-soaking.

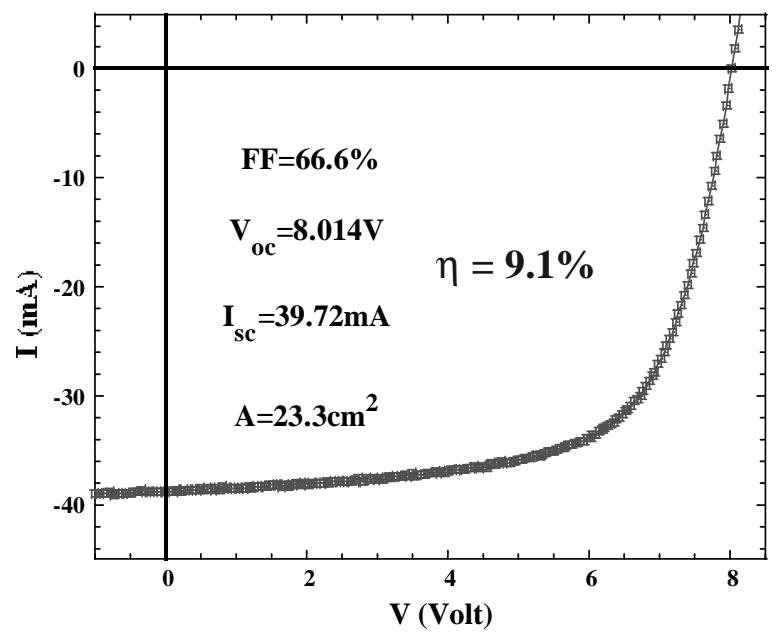

Fig. 6: A stabilized efficiency of a micromorph module of $9.1 \%$ could be achieved within our first module fabrication experiments.

\section{CONCLUSIONS}

In this study we investigated the application of the monolithic series connection concept to the micromorph (a-Si:H/ $\mu \mathrm{c}-\mathrm{Si}: \mathrm{H})$ tandem solar cell. Thereby, the laser scribing technique, already well-established for a-Si:H MW-manufacturing, has been tested for the thicker micromorph tandem cells.

Using our small size VHF-GD reactor $\left(8 \times 8 \mathrm{~cm}^{2}\right.$ electrode area), we succeeded with our first experiments in the fabrication of a stabilized micromorph module with aperture are efficiency of $9.1 \%$. This module consists of 6 segments and has a total aperture area of $23.3 \mathrm{~cm}^{2}$. These results prove that laser patterning and the monolithically integrated series connection is fully compatible with the micromorph tandem cell concept.

For fabrication of cells and modules, our own $\mathrm{ZnO}$ deposited by LP-CVD was used. These layers are scribed with an infrared laser without further problems.

We hold that further optimization with respect to micromorph cell deposition, LP-CVD ZnO TCO layers, module design and minimization of area losses due to scribing should lead us certainly to the fabrication of pin/pin micromorph modules with stable efficiencies above $10 \%$.

\section{Acknowledgements}

The Swiss Federal Office of Energy BfE/OFEN No. 36487 supported this work. 


\section{Reference}

[1] J. Meier, S. Dubail, J. Cuperus, U. Kroll, R. Platz, P. Torres, J.A. Anna Selvan, P. Pernet, N. Pellaton Vaucher Ch. Hof D. Fischer, H. Keppner, A. Shah, J. Non-Crystalline Solids 227-230, p. 1250 (1998).

[2] J. Meier, E. Vallat-Sauvain, S. Dubail, U. Kroll, J. Dubail, S. Golay, L. Feitknecht, P. Torres, S. Fay, D. Fischer, A. Shah, to be publ. in Solar Energy Materials and Solar Cells (2000).

[3] H. Keppner, J Meier, P. Torres, D. Fischer, A. Shah, Appl. Phys. A69, p. 169 (1999).

[4] K. Yamamoto, M. Yoshimi, Y. Tawada, Y. Okamoto, A. Nakajima. J. Non-Crystalline Solids. Vol. 266-269, p.1082-1087 (2000)

[5] K. Saito, M. Sano, K. Matuda, T. Kondo, T. Nishimato, K. Ogawa, I. Kajita, Proc. of $2^{\text {nd }}$ WCPVSEC, p. 351 (1998).

[6] H. Curtins, N. Wyrsch, A. Shah, Electron. Lett. 23, p. 228 (1987).

[7] D. E. Carlson, R. R. Arya, M. Bennett, L.-F. Chen, K. Jansen, Y.-M Li, J. Newton, K. Rajan, R. Romero, D. Talenti, E Twesne, F. Willing, L. Yang, $25^{\text {th }}$ IEEE, PVSC, p. 1023 (1996).

[8] S. Golay, J. Meier, S. Dubail, U. Kroll, A. Shah to be pub. in Proc. of $16^{\text {th }}$ EU PVSEC, (Glasgow, UK, May 2000.)

[9] S. Faÿ, S. Dubail, U. Kroll, J. Meier, Y. Ziegler, A. Shah to be publ. in Proc. of $16^{\text {th }}$ EPVSEC, (Glasgow, UK, May 2000).

[10] J. Meier , U. Kroll, S. Dubail, S. Golay, S. Faÿ, J. Dubail, A. Shah, 